\title{
TECHNOLOGIES FOR ASSESSMENT IN HIGHER EDUCATION. A SYSTEMATIC REVIEW
}

\author{
M.G. Veytia Buchely 1 , T. Linde-Valenzuela ${ }^{2}$ \\ ${ }^{1}$ Universidad Autónoma de Hidalgo (MEXICO) \\ 2 University of Málaga (SPAIN) \\ maria_veytia@uaeh.edu.mx,teresalv@uma.es
}

\begin{abstract}
In the current Higher Education framework, Informational Technologies (ICTs) have been implemented as a way to communicate and show contents, support the learning, promote distance-learning methodologies, enable new communications channels, as well as attending the assessment process. The learning assessment supporting by ICTs has become a reality which joins used method and enhance it, with all the opportunities that social technologies offer. This work presents a systematic review of the existing literature of the studies about using technologies for assessment in the context of Higher Education in the past decade, from 2008 to 2018. For that, the pedagogical models that underlie the application from one technology to another, also the techniques and tools used more and more currently, in each territory.

The selection of journal articles was made in consideration of database searching as Google Académico, WoS, Science Direct, Scielo, Redalyc and Latindex, using the keywords: assessment, educational assessment, educational technology, higher education... As well, taking into account the utility and relevance of the subject under study and the credibility and experience of the authors in this topic. The internal and external validity was considered in each of the revised papers.

The results evidence the raising importance of the use of ICTs for diagnostic, formative and summative assessment in Higher Education, using several tools as digital rubrics and portfolios, wikis, that favour the individual and collaborative work between students.
\end{abstract}

Keywords: assessment, educational assessment, educational technology, higher education, systematic review 